\title{
Effect of Biological Metacognitive Skills using Project-Based Learning Model
}

\author{
Irda Wahidah Nst ${ }^{1}$, Nurul Hidayah Nasution ${ }^{2)}$ \\ ${ }^{1)}$ Lecturer of STKIP Asy-Syafi'iyah, \\ ${ }^{2)}$ State Islamic University of North Sumatra \\ *Coresponding Author \\ Email : $\underline{\text { irdawahidah26@gmail.com }}$
}

\begin{abstract}
The purpose of this study was to determine the effect of biological metacognitive skills taught by a project-based learning model in class X MAS Al-Wasliyah 22 Tembung. The population in this study were all students of class X MAS Al-Wasliyah 22 Tembung which consisted of 3 classes. This type of research uses a quasi-experimental research sample taken by random sampling, namely class $X-A$ with a total of 40 students who are taught using a project-based learning model. The research instrument used a test of metacognitive skills using a questionnaire. The data analysis technique used the t test at a significant level of $=0.05$ with the help of SPSS 22.0. The results showed: there was a significant effect on biological metacognitive skills taught by the project-based learning model (thit $=2.05 ; P=0.043)$. The results of biological metacognitive skills that were learned using a projectbased model (86.14 \pm 3.8$)$ had a significant effect. As a follow-up to the results of this study, it is hoped that teachers can apply project-based learning models to ecosystem materials as an effort to improve the results of metacognitive skills.
\end{abstract}

Keywords: Metacognitive, Project- Based Learning Model

\section{INTRODUCTION}

Changes and developments in aspects of life need to be responded to with professional and high-quality educational performance. Educational performance requires efforts to reform and improve various aspects of education that support it, such as: changing and improving the curriculum, improving the quality of teachers, procuring textbooks, completing facilities and infrastructure and school laboratory equipment. Many efforts have been made by the government to improve the quality of education, but the results obtained have not been encouraging as revealed in the report on academic quality between nations through the Program for International Student Assessment (PISA, 2015) that the performance and mastery of Indonesian students' material is still relatively low. Respectively, the average achievement scores of Indonesian students for science, reading, and mathematics are ranked 62, 61, and 63 of the 69 countries evaluated.

One of the causes that are currently considered the most influencing and can explain this fact is the low thinking ability including metacognitive skills among students of various academic abilities. In such conditions, it is necessary to explore models to help students with low academic ability. One of the efforts that can be done to help groups of students with low academic ability is to implement a biology learning model in schools that has the potential to empower thinking skills and metacognitive skills.

Pratiwi (2016) said that students' metacognitive skills are indispensable in the ongoing learning process, because they determine students' cognitive abilities. If students use their metacognitive skills well, the learning outcomes obtained will also be better, because these students plan, develop, and evaluate the learning process carried out.

Metacognitive skills are very important for every student related to independence in learning. In principle, if it is associated with the learning process, metacognitive skills are a person's ability to control the learning process, starting from the planning stage, then monitoring 
progress in learning and simultaneously correcting if there are errors that occur during understanding the concept, to produce learning goals (Iskandar, 2014). . Students who have high metacognitive skills will be successful in learning. This is because students are able to apply the knowledge gained to overcome the problems they face.

Project-based learning models can improve students' problem-solving skills, besides project-based learning models can also improve student achievement as measured by tests. Tiantong (2013), revealed that the learning model in schools today is conventional learning that is out of the context of learning, students are not prepared to solve problems that occur today. Tiantong conducted research and concluded that the project-based learning model can increase students' multiple intelligence.

Project-based learning models are considered suitable for improving metacognitive skills, because metacognition has a direct positive relationship with academic achievement, meaning that the higher the metacognitive skills, the better the learning outcomes (Nuryana \& Sugiarto, 2013).

One of the biological materials that have a value under the KKM is ecosystem material. This is because the process of learning biology in schools is less innovative, learning media are also still not widely used. Conditions like this of course make learning less interesting so students tend to be passive, less responsive. Whereas the ecosystem material for the learning process should be better taught directly in nature because this kind of learning process emphasizes more on providing direct experience to develop competencies in order to explore and understand the natural surroundings scientifically so that it can help students to gain a deeper understanding of the natural surroundings, activities and activities. students who are not monotonous, can grow metacognitive skills, work and be scientific and communicate them as an important aspect of life skills so that with this learning process student learning outcomes are no longer under the teaching completeness criteria (KKM).

\section{RESEARCH METHODS}

This research includes a quasi-experimental. The research design was an experimental design with a pretest-posttest control group design using a project-based experimental class. The population in this study were all students of class X MAS Al-Wasliyah 22 Tembung. Sampling technique with cluster random sampling. In this study, data collection techniques to measure metacognitive skills used a questionnaire of 30 items. The test was carried out 2 times, namely the pretest which aims to obtain the initial ability level and the posttest to measure the results of biological metacognitive skills. The data analysis technique used unpaired $t$ test (independent sample $t$ test). Instrument validation is validated by experts.

\section{RESULTS AND DISCUSSION}

The research data is in the form of the average value of metacognitive skills to determine the effect of the results of being taught using a project-based learning model. The results of data processing showed that the average value of the results of metacognitive biology skills in the project-based group had a significant effect. The effect of the average value of metacognitive skills results is presented in table 1.

Table 1. The effect of the average value of metacognitive skills results

\begin{tabular}{|l|l|}
\hline Learning Model & Average Score \\
\hline Project Based & 86,14 \\
\hline
\end{tabular}


Differences in metacognitive skills learned with project-based learning models were analyzed by t-test. The results of the t-test obtained thit $=2.05 ; \mathrm{P}=0.043$. Thus, it can be concluded that there is an effect of metacognitive skills that are learned with a project-based learning model on ecosystem materials in class X MAS Al-Wasliyah 22 Tembung.

In the results of this study, it was found that the results of students biological metacognitive skills on ecosystem materials taught using a project-based model obtained the average value and standard deviation $(86.14 \pm 3.8)$.

This is because the project-based learning model is a student-centered learning model, namely students are given activities to play an active role in the learning process to be able to master the competencies of ecosystem materials that must be achieved in learning objectives, namely students are given the opportunity to create their own product.

The project-based model is a model in which students compose, discuss and present the projects they have prepared so that inputs are obtained from various parties, both fellow students and teachers (Yuli, 2015). The project-based model greatly affects biological metacognitive skills because at first students perform task analysis, namely using prior knowledge that is in accordance with ecosystem materials, using learning materials according to ecosystem materials, using learning resources such as in the surrounding environment, libraries that are in accordance with ecosystem materials. This happens because project-based learning focuses on concepts that involve students in project work activities, providing opportunities for students to work independently, constructing their knowledge and ultimately producing works or products and the results are then presented (Kamaruzaman, 2010).

Metacognition consists of two basic processes that take place simultaneously, namely monitoring progress when learning and making changes (Haryani, 2012). Munandar (2014) states that metacognition emphasizes an understanding of one's own abilities about what must be done in the learning process such as checking, planning, organizing, monitoring, predicting, and evaluating their own thinking processes.

Thus, based on the results of research, statistical testing and existing theories, it is proven that there is a significant effect of metacognitive skills taught by the project-based learning model. Thus, stating that $\mathrm{Ha}$ is accepted or Ho is rejected, it can be concluded that there is a significant effect of metacognitive skills on ecosystem materials that are taught using the project-based learning model in class X MAS Al-Wasliyah 22 Tembung

\section{CONCLUSION}

Based on the results of research findings and analyzes that have been carried out by researchers, several conclusions are obtained, namely: There are significant differences in project-based learning models on students' metacognitive skills in the ecosystem material of class X MAS Al-Wasliyah 22 Tembung. The results of students' metacognitive skills taught by the project-based learning model have a significant effect. 


\section{REFERENCES}

Haryani, S. 2012. Building Metacognitive and Characteristics of Prospective Teachers Through Problem-Based Analytical Chemistry Practicum Learning. Semarang: UNNES Press

Iskandar, S. M. 2014. Approach to Metacognitive Skills in Science Learning in the Classroom. ERUDIO. 2(2):13-20

Kamaruzaman, Baharuddin \& Azhar. 2010. Motivating Students Using PjBL Via e-Solms Technology. Word Applied Science Journal. 8 (9): 1086-1092

Munanadar, H. (2014). Improving Students' Mathematical Problem Solving Ability Through Learning With a Metacognitive Approach. National Seminar on Mathematics Education. National Seminar, Graduate Program STKIP Siliwangi Bandung. Bandung.

Nuryana, Eka and Bambang Sugiarto. 2013. The Relationship of Metacognition Skills With Student Learning Outcomes In The Material Of Oxidation Reduction Reactions (Redox) Class X-1 SMA Negeri 3 Sidorjo. Journal of Chemical Education. Surabaya: UNESA.

PISA. 2015. OECD PISA Results Executive Summary (http://dx.doi.org/10.1787/42)

Pratiwi, I., Suratno., and Moch Iqbal. 2016. Improving Metacognition Ability and Student Learning Outcomes with Process Skills Approach Through Think Pair Share in Class X-3 SMAN Yosowilangun Lumajang 2014/2015. UNEJ Educational Journal. 3(2): $22-28$

Tiantong, M. 2013. The Online Project Based Learning Model Based on Student's Multiple Intelligence. Bangkok. Department of Computer Education. 75 (3):1-5

Yuli, R \& Sri, H. 2015. Application of Project-Based Learning Model to Improve Metacognitive Skills. Journal of Chemical Education Innovation. 9 (2): 1596-1606 